\title{
Spectrophotometric and Principal Component Regression Chemometric Method for Simultaneous Determination of Hypertension Drug's in Commercial Pharmaceutical
}

\author{
A. Hakan Aktas (Corresponding author) \\ Suleyman Demirel University, Science and Art Faculty \\ Department of Chemistry, Isparta, Turkey \\ E-mail: hakanaktas@sdu.edu.tr \\ Enes Ciraci \\ Suleyman Demirel University, Graduate School of Natural and Applied Sciences \\ Department of Chemistry, Isparta, Turkey \\ E-mail: enesciraci@hotmail.com
}

The research is financed by Süleyman Demirel University Scientific Project FYL-2018-5738

\begin{abstract}
In this study, the simultaneous determination of Lisinopril (LIS) and Hydrochlorothiazide (HCT) in drug samples by chemometric approaches using UV spectrophotometry has been reported as a simple alternative to using separate models for each component. Spectra of LIS and HCT were recorded at several concentrations within their ranges and were used to compute the calibration mixture between wavelengths 200 and $350 \mathrm{~nm}$ at an interval of $5 \mathrm{~nm}$ was used for data acquisition. Principal component regression was used for chemometric analysis of data and the parameters of the chemometric procedures were optimized. The analytical performances of this chemometric method was characterized by predicted residual error sum of squares (PRESS), standard error of prediction (SEP) and recoveries (\%) and were compared with each other. A series of synthetic solution containing different concentrations of LIS and HCT were used to check the prediction ability of the principal component regression. This method was successfully applied to real samples, with no interference from excipients as indicated by recovery study results. The outcomes acquired in this examination firmly urge us to apply these strategies for a standard investigation and quality control of the two medications.
\end{abstract}

Keywords: Lisinopril, Hydrochlorothiazide, Principal Component Regression

DOI: $10.7176 / \mathrm{JSTR} / 5-4-03$

\section{Ticari İlaç Tabletlerinde Hipertansiyon İlaçlarının Eşzamanlı Tayini İçin Spektrofotometrik ve Temel Bileșen Regresyon Kemometrik Yöntemi}

Özet

Bu çalışmada, UV spektrofotometrisi kullanılarak kemometrik yaklaşımlarla ilaç örneklerinde Lisinopril (LIS) ve hidroklorotiazid (HCT) in eş zamanlı olarak belirlenmesi ve her bir bileşen için ayrı modeller kullanmak için basit bir alternatif yöntem çalışılmıştır. Çeşitli konsantrasyonlarda LIS ve HCT' nin spektrumları için 200 ve $350 \mathrm{~nm}$ dalga boyları arasındaki kalibrasyon karışımlarını $5 \mathrm{~nm}$ aralıklarla hesaplamak için kullanıldı. Verilerin kemometrik analizi için temel bileşen regresyonu kullanıldı ve kemometrik prosedürlerin parametreleri optimize edildi. $\mathrm{Bu}$ kemometrik yöntemin analitik performansları artıkların hatalarının toplamının kareleri (PRESS), tahmini standart hata (SEP) ve geri kazanımlar (\%) ile karakterize edildi ve birbirleri ile karşılaştırıldı. Ana bileşen regresyonunun tahmin yeteneğini kontrol etmek için farklı konsantrasyonlarda LIS ve HCT içeren bir dizi sentetik karışım kullanıldı. $\mathrm{Bu}$ yöntem gerçek numunelere başarılı bir şekilde uygulandı, geri kazanım çalışması sonuçlarında belirtildiği gibi yardımcı maddelerden etkilenmedi. Bu incelemede elde edilen sonuçlar, bu stratejileri iki ilacın standart araştırması ve kalite kontrolü için bu stratejileri uygulamaya teşvik etmektedir. 
Anahtar Kelimeler: Lisinopril, Hidroklorotiazid, Temel Bileşen Analizi

\section{Introduction}

Hypertension (high blood pressure), such as high blood pressure resulting. Blood pressure is the force exerted by blood against the walls of the blood vessels. Pressure depends on the job of the heart and the resistance of the blood vessels. The American Heart Association (AHA) defines hypertension as a blood pressure of more than $130 / 80$ millimeters $(\mathrm{mm} \mathrm{Hg}$ ) from the medical data published in November 2017.The World Health Organization (WHO) says that the growth of processed food industry affects the amount of salt in diets worldwide, and that it plays a major role in hypertension.

Lisinopril (S)-1-[N²-(1-carboxy-3-phenyl propyl)-L-lysyl]-L-proline dihydrate a lysine analogue of enalaprilate, the color of lisinopril is a white, state crystalline, no smell and powder having molecular weight of 441.52 and molecular formula $\mathrm{C}_{21} \mathrm{H}_{31} \mathrm{~N}_{3} \mathrm{O}_{5} .2 \mathrm{H}_{2} \mathrm{O}$. It is soluble in water and sparingly in methanol, differs from captopril by lacking the sulfhydryl group. It is indicated for the treatment of hypertension, heart failure and acute myocardial infarction. It is indicated as adjunctive therapy in the management of heart failure in patients who are not responding adequately to diuretics and digitals. It is used to treat hypertension, myocardial infarction, heart failure and diabetic nephropathy or retinopathy (Figure 1a) (Naveed, 2014).

Hydrochlorothiazide [HCT, 6-chloro-3,4-dihydro-2H-1,2,4-benzothiadiazine-7- sulphonamide -1, 1dioxide,] is a diuretic acting on distal convoluted tubule. Hydrochlorothiazide having molecular weight 297.7 and molecular formula $\mathrm{C}_{7} \mathrm{H}_{8} \mathrm{ClN}_{3} \mathrm{O}_{4} \mathrm{~S}_{2}$. Because of their synergistic anti-hypertensive action, lisinopril and hydrochlorothiazide are available on the market as a combined dosage form (Figure 1b) (Emir and Aktaş, 2015).

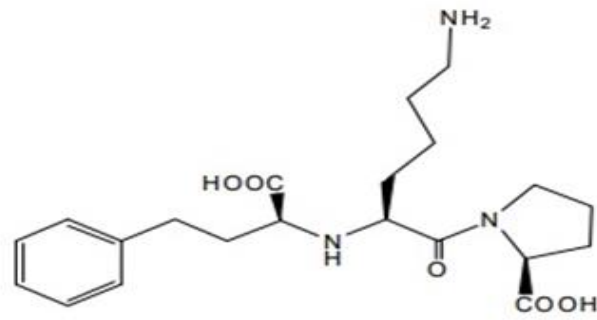

a)<smiles>NS(=O)(=O)c1cc2c(cc1Cl)NCNS2(=O)=O</smiles>

b)

Figure 1. Structure of the drugs a) LIS b) HCT

The literature survey reveals that several methods were reported for the individual estimation of LIS and HCT. Several methods have been published for the determination of LIS and HCT in pharmaceutical formulations and biological samples including spectrophotometry (Erk, 1998; El-Gindy et al, 2001), LCMS-MS (Sa-hah et al, 2014), spectrophotometric and spectrofluorimetric and LC (El-Yazbi et al, 2001), HPLC (Sane et al, 1992) and capillary electrophoresis (Hillaert et al, 2001).

The multivariate calibration techniques use full spectrum, full automation, multivariate data analysis and the reduction of noise and the advantages of the selection calibration model. In addition these multivariate calibrations do not need any separation procedure, they are very cheap, very easy to apply and very sensitive. For these reasons these multivariate techniques are popular today.

In this study a powerful chemometric method was applied to analyze the synthetic mixtures and tablets consisting of LIS and HCT in the presence of interferences of the absorption spectra. The application of chemometrics allows the interpretation of multivariate data and is vital to the success of the simultaneous determination of the clinical drugs.

\section{Experimental Section}

\subsection{Apparatus}

A Shimadzu (Model UV-1700) UV-Visible spectrometer (Shimadzu, Kyoto, Japan), equipped with $1 \mathrm{~cm}$ matched quartz cells was used for spectrometric measurements.

\subsection{Standard solutions}

All materials used were of analytical grade. Stock solutions of $10 \mathrm{mg} / 100 \mathrm{~mL}$ LIS and HCT were prepared in methanol. The solutions were stable for the least two weeks if they had been stored in a cool $\left(<25^{\circ} \mathrm{C}\right)$ and dark place. 


\subsection{Pharmaceutical preparations}

A commercial drug preparations; Sinoretik ${ }^{\circledR}$ tablet produced by Zentiva, Turkey, containing $20 \mathrm{mg}$ lisinopril and $12.5 \mathrm{mg}$ hydrochlorothiazid per tablet, was analyzed by the proposed chemometric techniques.

2.4. Procedure for dosage form

A precisely weighed pummeled tablets comparable to $100 \mathrm{mg}$ of the considered medications was separated with $10 \mathrm{~mL}$ of methanol, weakened with water, and sonicated for around $30 \mathrm{~min}$. The concentrates were separated into $100 \mathrm{~mL}$ volumetric carafes at that point washed and weakened to volume with refined water. Aliquots these arrangements were moved into a progression of $10 \mathrm{~mL}$ volumetric jars and the examination were finished as spectrometric method. Every one of the systems were connected to the last arrangement.

\subsection{Chemometric method}

PCR is factor analysis method, based on a two stage procedure; a calibration step, in which a mathematical model is built by using component concentrations and spectral data from a set of references, followed by a prediction step in which the model is used to calculate the concentrations unknown sample from its spectrum. This method is also called factor methods because they transform the original variables into a smaller number of orthogonal variables called factors or principal components (PCs), which are linear combinations of the original variables. When multivariate calibration approaches are applied in spectrophotometric multi component analysis, a relationship between spectral and concentration data from reference samples, representing the variables of the system, is established. A new matrix constituted by the new variables PCs and scores is built. The calculation of this new matrix is planned by algorithm specific to the regression method adopted.

\section{Results and Discussion}

Figure 2 shows the absorption spectra for LIS and HCT and their mixture in methanol. In order to build the chemometric calibration, a training set was randomly prepared by using the standard mixture solution containing $1.60-8.0 \mu \mathrm{g} / \mathrm{mL}$ LIS and $1.0-5.0 \mu \mathrm{g} / \mathrm{mL} \mathrm{HCT} \mathrm{in} \mathrm{the} \mathrm{variable} \mathrm{proportions}$ as shown in Figure 3. The absorbance data matrix were obtained by measuring at the 13 wavelengths with the intervals $\Delta \lambda=5 \mathrm{~nm}$ in the $200-400 \mathrm{~nm}$ spectral region. The prepared calibrations of three techniques using the absorbance data sets were used to predict concentration of the unknown values of LIS and HCT in their mixture. Linearity range was $0.40-2.0 \mu \mathrm{g} / \mathrm{mL}$ for LIS and $1.0-5.0 \mu \mathrm{g} / \mathrm{mL}$ for HCT in the multivariate calibration proposed.

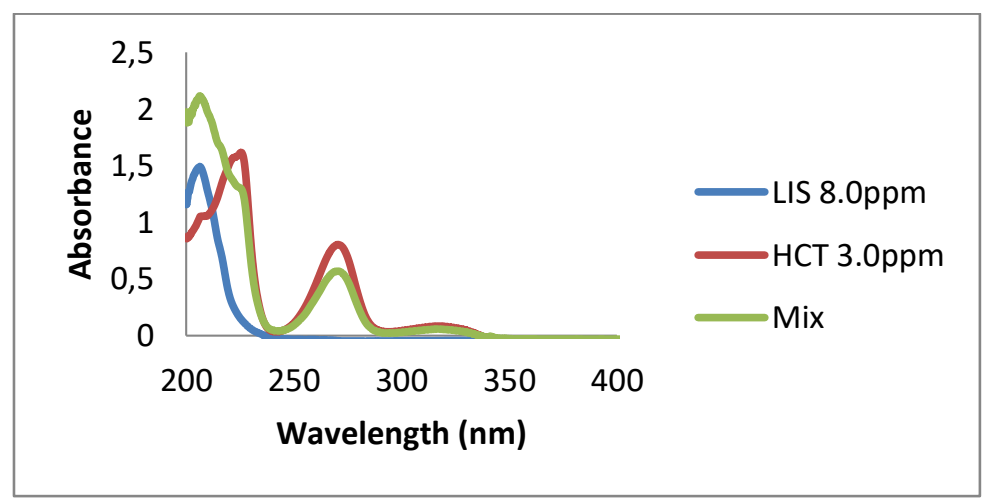

Figure2. Original absorption spectra of $8.0 \mu \mathrm{g} / \mathrm{mL} \mathrm{LIS,} 3.0 \mu \mathrm{g} / \mathrm{mL}$ HCT and their mixture in methanol 


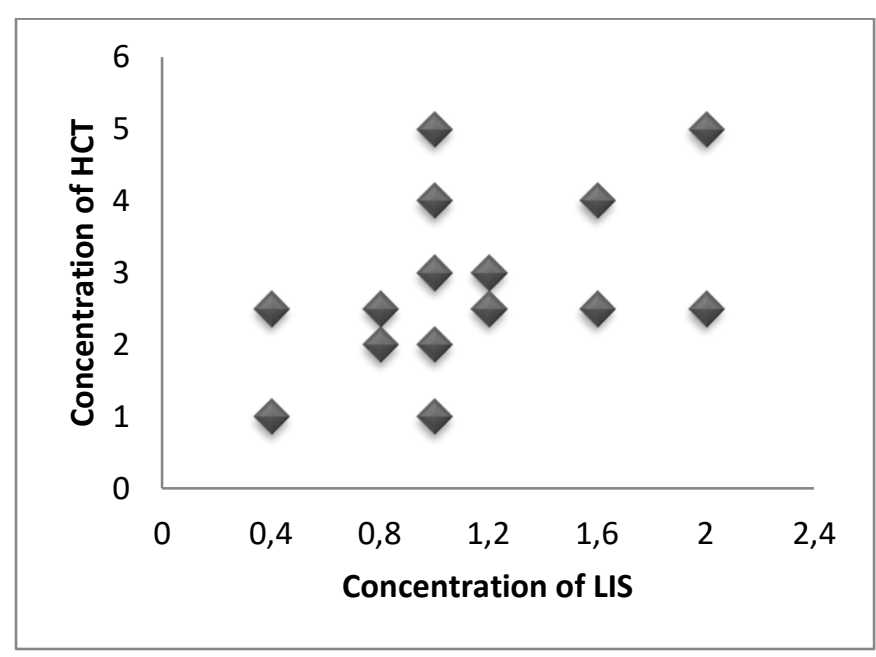

Figure 3. Concentration set design for the preparation of PCR calibration

Figure 2 shows the absorption spectra for LIS and HCT and their mixture in methanol.

A calibration for each technique was computed in the MINITAB 16.0 and PLS Toolbox 4.0 software by using set consisting of two drugs and their absorbance data. The multivariate calibrations of three techniques were used to predict the unknown concentrations of LIS and HCT in the samples.

Some statistical parameters were given for the validation of the constructed calibrations for the training set and synthetic binary mixtures of both drugs. The application competence of a calibration model can be explained in several ways. We can also examine these results numerically. One of the best ways to do this by examining the predicted residual error sum-of-squares or PRESS. To calculate PRESS we compute the errors between the expected and predicted values for all the samples, square them, and sum them together.

$$
\operatorname{PRESS}=\sum_{i=1}^{n}\left(C_{i}^{\text {added }}-C_{i}^{\text {found }}\right)^{2}
$$

Strikingly speaking, this is not a correct way to normalize the PRESS values when not all of the data sets contain the same number of samples. If we want correctly compare PRESS values for data sets that contain differing numbers of samples, we should convert to standard error of prediction (SEP), which is given by following formula.

$$
\mathrm{SEP}=\sqrt{\frac{\sum_{i=1}^{n}\left(C_{i}^{\text {added }}-C_{i}^{\text {found }}\right)^{2}}{n-1}}
$$

Where $C_{i}^{\text {added }}$ the added concentration of drug is, $C_{i}^{\text {found }}$ is the found concentration of drug and $\mathrm{n}$ is the total number of the synthetic mixtures. The SEP can provide a good measure of how well, on average, the calibration model performs. Often, however, the performance of the calibration model varies depending on the analyte level. In the application of two chemometric techniques to the synthetic mixtures containing two drugs in variable compositions, the mean recoveries and relative standard deviations for PCR was found to be $100.4710 \%, 0.2755$ and $100.1360 \%, 0.0159$ respectively for LIS and for HCT (Table 1). 
Table 1. Results obtained for LIS and HCT indifferent synthetic mixtures by using PCR technique

\begin{tabular}{|c|c|c|c|c|c|}
\hline \multicolumn{3}{|c|}{ Mixture $(\mu \mathrm{g} / \mathrm{mL})$} & \multicolumn{2}{|c|}{ Recovery } & \multirow[b]{2}{*}{ HCT } \\
\hline LIS & HCT & LIS & HCT & LIS & \\
\hline 0.40 & 1.00 & 0.4009 & 1.0011 & 100.2369 & 100.1179 \\
\hline 0.80 & 2.00 & 0.8022 & 2.0029 & 100.2800 & 100.1480 \\
\hline 1.20 & 3.00 & 1.2056 & 3.0043 & 100.4715 & 100.1461 \\
\hline 1.60 & 4.00 & 1.6078 & 4.0059 & 100.4877 & 100.1483 \\
\hline 2.00 & 5.00 & 2.0104 & 5.0072 & 100.5229 & 100.1457 \\
\hline 1.00 & 1.00 & 1.0003 & 1.0012 & 100.0339 & 100.1264 \\
\hline 1.00 & 2.00 & 1.0042 & 2.0023 & 100.4230 & 100.1199 \\
\hline 1.00 & 3.00 & 1.0057 & 3.0042 & 100.5715 & 100.1421 \\
\hline 1.00 & 4.00 & 1.0079 & 4.0057 & 100.7985 & 100.1437 \\
\hline 1.00 & 5.00 & 1.0111 & 5.0069 & 101.1117 & 100.1384 \\
\hline 0.40 & 2.50 & 0.4028 & 2.5034 & 100.7010 & 100.1394 \\
\hline 0.80 & 2.50 & 0.8040 & 2.5032 & 100.5039 & 100.1301 \\
\hline 1.20 & 2.50 & 1.2069 & 2.5023 & 100.5771 & 100.0941 \\
\hline 1.60 & 2.50 & 1.6031 & 2.5035 & 100.1967 & 100.1431 \\
\hline \multirow[t]{3}{*}{2.00} & 2.50 & 2.0028 & 2.5038 & 100.1445 & 100.1526 \\
\hline & & & Mean & 100.4710 & 100.1360 \\
\hline & & & RSD* & 0.2755 & 0.0159 \\
\hline
\end{tabular}

\section{RSD*: Relative Standard Deviation}

According to the added concentration and the concentration found in samples, the SEP and PRESS values of PCR technique was calculated 0.0809 and 10.1245 respectively for LIS, 0.0706 and 0.0949 respectively for HCT (Table 3).

Table 3. Statistical parameters in the calibration-prediction for PCR method

\begin{tabular}{|lll|} 
Parameter & LIS & \multicolumn{2}{c|}{ HCT } \\
\hline PRESS & 0.1245 & 0.0949 \\
\hline SEP & 0.0809 & 0.0706 \\
\hline $\mathbf{r}$ & 0.9999 & 0.9999 \\
\hline Intercept & 0.9944 & 1.0011 \\
\hline Slope & 0.0083 & 0.0006 \\
\hline
\end{tabular}

Accuracy and precision for the analysis of LIS and HCT substances in the prepared synthetic mixtures at three different concentration levels $(0.40,0.80$ and $1.20 \mathrm{~g} / \mathrm{mL}$ for LIS and 1.00, 2.00 and $3.00 \mathrm{~g} / \mathrm{mL}$ for HCT) in intra-day $(n=6)$ and inter-day $(n=6)$, was tested for the applicability of the proposed chemometric methods. The calculated results for percent relative error, standard deviation and relative standard deviation were presented in table 4 . Good accuracy and precision were observed for the results obtained by PCR calibration. 
Table4. Accuracy and precision results for PCR

\begin{tabular}{|c|c|c|c|c|c|c|c|c|c|c|c|}
\hline \multicolumn{12}{|c|}{ Intra- day $(n=6)$} \\
\hline \multicolumn{2}{|c|}{ Added $(\mu \mathrm{g} / \mathrm{ml})$} & \multicolumn{5}{|c|}{ LIS } & \multicolumn{5}{|c|}{ HCT } \\
\hline LIS & HCT & Found & SD & $\% \mathrm{BSS}$ & $\% \mathrm{RE}$ & Recovery $(\%)$ & Found & SD & $\% \mathrm{BSS}$ & $\% \mathrm{RE}$ & Recovery $(\%)$ \\
\hline 0.40 & 1.00 & 0.4009 & 0.0115 & 0.0008 & 0.2369 & 100.2369 & 1.0012 & 0.2425 & 0.1179 & 0.1179 & 100.1179 \\
\hline 0.80 & 2.00 & 0.8040 & 0.0078 & 0.0007 & 0.5039 & 100.2800 & 2.0024 & 0.2024 & 0.1199 & 0.1199 & 100.1481 \\
\hline \multirow[t]{6}{*}{1.20} & 3.00 & 1.2069 & 0.0074 & 0.0007 & 0.5771 & 100.4716 & 3.0042 & 0.2049 & 0.1421 & 0.1421 & 100.1461 \\
\hline & & & & & $\overline{\mathbf{x}}$ & 100.3295 & & & & $\overline{\mathbf{x}}$ & 100.1374 \\
\hline & & & & & SD & 0.1249 & & & & SD & 0.01688 \\
\hline & & & & & BSS & 0.0012 & & & & BSS & 0.0001 \\
\hline & & & & & LOD & 0.4123 & & & & LOD & 0.0055 \\
\hline & & & & & LOQ & 1.2495 & & & & LOQ & 0.1688 \\
\hline
\end{tabular}

Inter-day $(\mathrm{n}=6)$

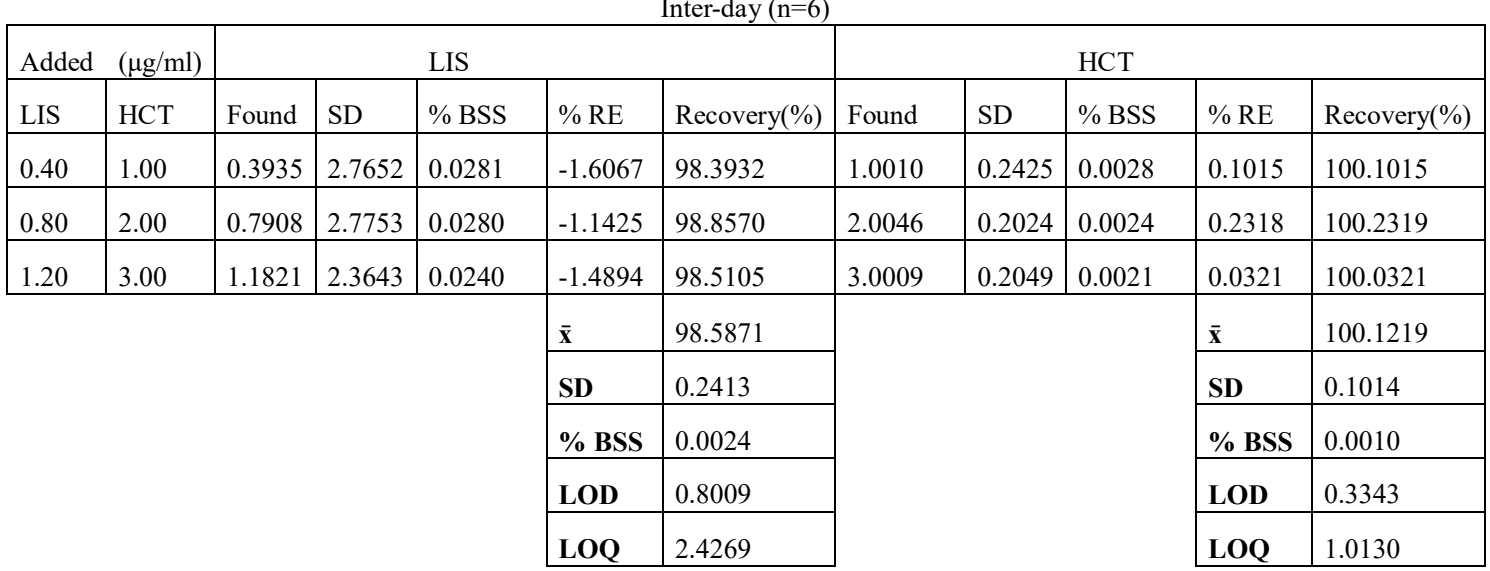

The linear regression analysis of the added concentration and the concentration found in the synthetic mixtures were realized for each drug and for each calibration technique. In this regression analysis, the correlation coefficient (r), intercept, slope and relative standard deviation values were found satisfactory for the proposed chemometric technique in Table 3. As can be seen, all the statistic values indicated that all techniques are convenient for the determination of two drugs in synthetic mixtures.

A summary of the assay results for the pharmaceutical formulation is given Table5. The results of all methods were very to each other as well as to the label value of commercial drug formulation.

Table 5. Assay results for the pharmaceutical formulation (mg/tablet)

\begin{tabular}{|lr|} 
Drug & PCR \\
\hline LIS & \\
Mean \pm SD* & $20.02 \pm 0.08$ \\
HCT & \\
Mean \pm SD* & $12.50 \pm 0.06$ \\
\hline
\end{tabular}

Results obtained are average of six experiments for each technique.

*SD : Standard deviation 


\section{Conclusion}

The powerful chemometric method in spectrophotometric investigation, PCR, was proposed for the synchronous assurance of LIS and HCT in binary blends. These strategies were connected with extraordinary accomplishment to a business pharmaceutical tablets. The goals of exceptionally covering medication blends was accomplished by the utilization of PCR method. A determination of working wavelength having high relationship esteems with fixation because of impedance originating from framework test or extra analytes outside the working extent. As indicated by the got outcomes, it was seen that the PCR strategy gave more exact outcomes in this mix of three drugs. The proposed chemometric method can be connected for the normal examination of two medications in the tablet definition with no from the earlier concoction partition and without tedious.

\section{Acknowledgement}

This research work has been supported by research grants from Süleyman Demirel University Scientific Research Project FYL-2018-5738.

\section{References}

Naveed S., (2014). Analytical determination of lisinopril using UV spectrophotometer and HPLC: An overview. Modern Chemistry \& Applications, 2:137.

Emir, Y., Aktaş, A.H., (2015). Spectrometric determination of irbesartan and hydrochlorothiazide in tablets by principal component regression and partial least squares calibration approach. ChemXpress, 8(3), 153-157.

Shah, J. V., Shah, P. A, Shah, P.V., Sanyal, M., Shrivastav, P.S., (2017). Fast and sensitive LCMS/MS method in negative ionization mode for the simultaneous determination of lisinopril and hydrochlorothiazide in human plasma. J. Pharm. Anal. 7(3), 163-169.

El-Yazbi, F.A., Abdine, H.H., Shaalan, R.A., (1999). Spectrophotometric and spectrofluorimetric methods for the assay of lisinopril in single and multicomponent pharmaceutical dosage forms. J. Pharm Biomed Anal, 19, 819-827.

Hillaert, S., De Grauwe, K., Van den Bossche, W., (2001). Simultaneous determination of hydrochlorothiazide and several inhibitors of angiotensin-converting enzyme by capillary electrophoresis. J Chromatog , 924, 439-449.

Sane, R.T., Valiyare, G.R., Deshmukh, U.M., Singh, S.R., Sodhi, R., (1992). Simultaneous HPLC determination of lisinopril and hydrochlorothiazide from its pharmaceutical preparations. Indian drugs, 29, 558-560.

El-Gindy, A., Ashour, A., Abdel-Fattah, L., Shabana, M., (2001). Spectrophotometric, septrofluorimetric and LC determination of lisinopril. J of Pharm and Biomed Anal, 25, 913-922.

Erk, N., (1998). Comparative study of the ratio spectra derivative spectrophotometry and Vierordt's method applied to the analysis of lisinopril and hydrochlorothiazide in tablets. Spectroscopy Letters, 31,633-645. 